University of Colorado Law School

Colorado Law Scholarly Commons

Books, Reports, and Studies

Getches-Wilkinson Center for Natural

Resources, Energy, and the Environment

1995

The Law of the Colorado River: Coping with Severe Sustained

Drought

Lawrence J. MacDonnell

David H. Getches

William C. Hugenberg, Jr.

University of Colorado Boulder. Natural Resources Law Center

Follow this and additional works at: https://scholar.law.colorado.edu/books_reports_studies

Part of the Water Law Commons, and the Water Resource Management Commons

\title{
Citation Information
}

Lawrence J. MacDonnell, David H. Getches \& William C. Hugenberg, Jr., The Law of the Colorado River: Coping with Severe Sustained Drought (Natural Res. Law Ctr., Univ. of Colo. Sch. of Law 1995). 


\section{William A. Wise Law Library
Colorado \\ UNIVERSITY OF COLORADO BOULDER

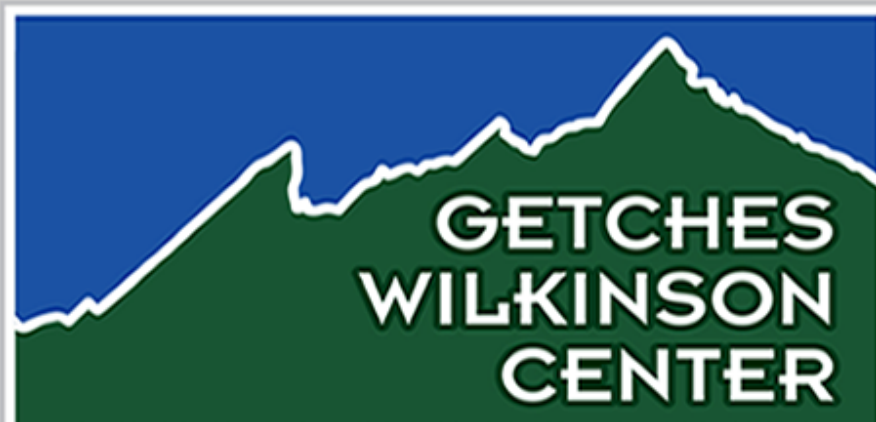 \\ FOR NATURAL RESOURCES, ENERGY, AND THE ENVIRONMENT \\ Getches-Wilkinson Center Collection}

LaWrence J. MacDonnell, David H. Getches \& William C. HugenberG, JR., THe LAW OF THE Colorado River: Coping With SeVEre Sustained Drought (Natural Res. Law Ctr., Univ. of Colo. Sch. of Law 1995).

Reproduced with permission of the Getches-Wilkinson Center for Natural Resources, Energy, and the Environment (formerly the Natural Resources Law Center) at the University of Colorado Law School. 
THE LAW OF THE COLORADO RIVER:

COPING WITH SEVERE SUSTAINED DROUGHT

Lawrence J. MacDonnell

David H. Getches

William D. Hugenberg, Jr.

Boulder, Colorado

NRLC Occasional Paper Series

Natural Resources Law Center

October 1995 


\title{
THE LAW OF THE COLORADO RIVER: COPING WITH SEVERE SUSTAINED DROUGHT ${ }^{1}$
}

\author{
Lawrence J. MacDonnell, David H. Getches, and William C. Hugenberg. Jr. ${ }^{2}$
}

\begin{abstract}
The waters of the Colorado River are divided among seven states according to a complex "Law of the River" drawn from interstate compacts, international treaties, statutes, and regula. tions. The Law of the River creates certain priorities among the states and the Republic of Mexico, and in the event of a severe sustained drought, the Law of the River dictates the distribution of water and operation of the elaborate reservoir system. Earlier work indicated that there is remarkable resilience in the system for established uses of water in the Lower Basin of the Colorado River. This work shows, based on an application of the Law of the River using computer modeling of operations of facilities on the Colorado River, that there may be serious environmental consequences and related legal restraints on how the water is used in times of shortage and that the existing legal and institutional framework governing the Colorado River does not adequately address all the issues that would be raised in a severe sustained drought. Several possible legal options for dealing with drought in the context of the Law of the River are identified.

(KEY TERMS: social and political; water law; water policy/regulation/decisionmaking; water resources planning; watershed management.)
\end{abstract}

\section{INTRODUCTION}

In November 1922, representatives of the seven Colorado River Basin states met, under the chairmanship of Secretary of Commerce Herbert Hoover, at Bishop's Lodge near Santa Fe, New Mexico, to "divide the waters" of the Colorado River in a manner intended to avert almost certain legal warfare (Hundley, 1975). Foremost on the mind of W. F. McClure, the representative from California, was attaining a clear (and substantial) entitlement of Colorado River water for his state, thereby opening the way for congressional authorization of the funds needed to build what became Hoover Dam and the All American Canal.
Similarly, Delph Carpenter, the Colorado representative and arguably the most influential of all the state representatives, was committed to ensuring the opportunity of his state (and others such as New Mexico, Utah, and Wyoming that were growing more slowly than California) to develop and use Colorado River water in the future. Unfortunately, the negotiators believed they were dividing an annual average flow of 16.4 million acre-feet (measured at Lee Ferry). However, based on subsequent long-term tree-ring. analysis, the actual annual average flow of the Colorado River appears to be more like 13.5 million acre-feet (Stockton and Jacoby, 1976; Kneese and Bonem, 1986).

When the parties were unable to agree on specific allocations for each of the participating states, Hoover saved the negotiations from failure by proposing to divide the available water between an "Upper" and a "Lower" Basin with the geographic division at Lee Ferry in northern Arizona. This agreement - which was eventually adopted by Congress as the Colorado River Compact ("Compact") - allocates 15 million acre-feet ("maf") of annual "exclusive beneficial consumptive use," 7.5 maf each to the Upper and Lower Basins, with an additional 1 maf to the Lower Basin. The Compact also anticipated additional water being committed to Mexico and a future allocation to the two Basins of "surplus" water. Given the misapprehension concerning the amount of water actually available, the operative provision of the Compact is Article III(d), which commits the Upper Basin to deliver at Lee Ferry 75 maf during every consecutive ten-year period (i.e., a moving ten-year average of 7.5 maf per year).

\footnotetext{
'Paper No. 95060 of the Waler Resources Bulletin. Discussions are open until June 1, 1996.

2Respectively, Lawyer and Consultant, Sustainability Initiatives, 22(50) Baseline Rond, Suite 101, Boulder. Colorado 80302 (former Director, Nalural Resources Law Center); Interim Director, Natural Resources Law Center, University of Colorade School of Law, Campus Box 401. Boulder, Colorado 80309-0401; and Attorney, Fredericks, Peleyger, Hester \& White, 1881 9th St., Suite 216 , E:نider, Colorado 80302.
} 
Perhaps most fundamentally, the Compact was intended to provide a sense of certainty to the parties. Lower Basin states and Upper Basin states each believed they were obtaining rights to use consumptively at least their respective expressed apportionment of Colorado River water. The Lower Basin states (certainly California) expected to develop and use more than this minimum amount. Since none of the parties expressed any real concern with the possibility of long-term drought, the Compact makes no provision for dealing with shortages of water.

This article addresses the ways in which the interstate compacts, international treaties, statutes, and regulations, known collectively as "The Law of the River," affect allocation decisions likely to be confronted in the event of a long-term, severe drought. The analysis is organized in a manner familiar to those conversant with the prior appropriation doctrine: according to legal priority. While the Law of the River is not technically a priority system, as a practical matter it does operate to create either express or implied priorities among those with legally recognized allocations of water. It establishes priorities between the United States and Mexico, between rights which pre- and post-date the Colorado River Compact, between the Upper and Lower Basins, and among uses of compact-allocated water within both the Lower and Upper Basins. These priorities are discussed in this article as are their implications for water allocation in the event of a prolonged and severe drought within the Colorado River Basin. Finally, the implications of water quality and endangered species protection are considered, since, under certain circumstances, legal requirements associated with these concerns are capable of trumping other water use priorities.

At the outset, it is important to acknowledge the extraordinary efforts already made to "drought-proof" users of Colorado River water, particularly those in the Lower Basin. Water storage facilities with a capacity roughly four times the average annual flow of the river have been constructed, almost all by the Bureau of Reclamation (see Map of the Colorado River Basin, Figure 1). Under ordinary circumstances, such massive storage should render issues of priority largely moot. However, under the extreme scenarios of prolonged drought investigated in this project, allocative priorities become significant. During periods of severe, sustained drought in the Colorado River Basin, water use decisions would presumably be made on the basis of the priorities derived from the Law of the River. This article seeks to explicate priorities, to identify areas of uncertainty, and to suggest the need for added flexibility in the existing allocation system to improve its ability to satisfy demands on the Colorado River in times of prolonged drought.

\section{WATER FOR MEXICO}

Under our interpretation of the Law of the River, the treaty-based delivery obligation to Mexico is the senior priority on the Colorado River. The 1944 "Treaty with Mexico Respecting Utilization of Waters of the Colorado and Tijuana Rivers and of the Rio Grande" guaranteed 1.5 maf per year of Colorado River water to Mexico. Efforts to clarify Mexico's claim to the Colorado River had been underway for many years (Hundley, 1966). Article III(c) of the 1922 Compact recognized the likelihood of such an agreement and provided that water for Mexico should be supplied from the unallocated "surplus" thought to be available, with any "deficiency" to be borne equally by the Upper Basin and the Lower Basin. Since there is, on average, no long-term unallocated surplus water in the river, the effect of this provision is to obligate both the Upper and Lower Basins each to ensure the annual availability to Mexico of 750,000 acre-feet of Colorado River water.

As a treaty commitment anticipated and agreed to in a congressionally approved interstate compact, the delivery obligation to Mexico is legally binding even during severe, sustained drought. Indeed, the priority of the delivery obligation to Mexico is reflected in the operation of the Glen Canyon Dam. The Colorado River Basin Project Act of 1968 directed the Secretary of the Interior to develop long-term operating criteria for operation of Glen Canyon and other Upper Basin dams authorized by the Colorado River Storage Project Act of 1956. Highest on the list of priorities to be satisfied under the operating criteria was the Upper Basin's delivery obligation under the treaty. Moreover, unlike much of the Law of the River, the 1944 Treaty with Mexico explicitly addresses the possibility of a severe drought. Thus, Article 10 states:

In the event of extraordinary drought or serious accident to the irrigation system in the United States, thereby making it difficult for the United States to deliver the guaranteed quantity of $1,500,000$ acre-feet $(1,850,234,000$ cubic meters) a year, the water allocated to Mexico under subparagraph (a) of this Article will be reduced in the same proportion as consumptive uses in the United States are reduced.

In other words, an "extraordinary drought" must make it "difficult" to meet the treaty obligation. Just how this determination is to be made remains 


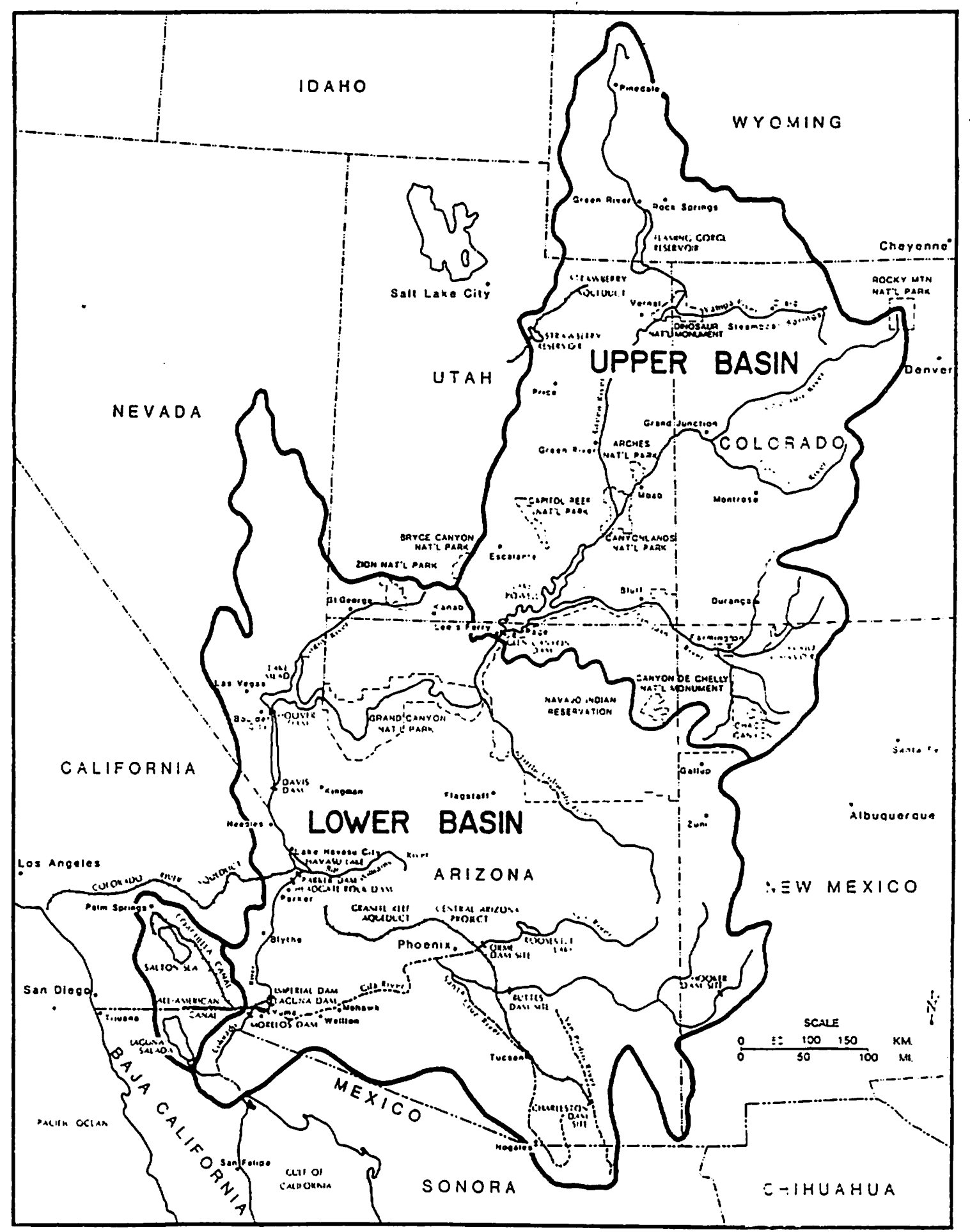

Figure 1. Map of Colorado River Basin.

(Source: Gary D. Weatherford and F. Lee Brown, New Courses for the Colorado River, _g. xx, 1986.)

unclear; however, under some circumstances, the delivery obligation can be reduced. The formula is based on a reduction in consumptive uses in the United States. Presumably, this means that the Upper and Lower Basins can reduce their deliveries to Mexico by the percentage that the drought-caused reductions in their consumptive uses of Colorado River water represent to their average historical consumptive uses of this source of supply, although this is far from clear. Indeed, the meaning of "consumptive" uses - a term used in the 1922 Compaci - is also unclear (Getches, 1985, pp. 423.424). 
MacDonnell, Getches, and Hugenberg, Jr.

\section{PRESENT PERFECTED RIGHTS}

Next in seniority are tribal reserved water rights and other "present perfected rights" that pre-date the Colorado River Compact. Article VIII of the Colorado River Compact states that "[p]resent perfected rights to the beneficial use of water of the Colorado River System are unimpaired by this compact." At the time the Compact was being negotiated, the Reclamation Service estimated that nearly 2.5 million acres of land were being irrigated in the United States with Colorado River water (Hundley, 1975, at 146-47). Present perfected rights are not further defined, but they presumably encompassed all consumptive uses already in being in 1922.

Among these "present perfected rights" were those controlled by irrigators in the Imperial Valley of California, who had been periodically devastated by floods and were largely dependent on diversions from the Colorado River in Mexico. The 1928 Boulder Canyon Project Act satisfied the desires of this very active contingent of Californians by authorizing the construction of Hoover Dam for river regulation and flood control and by providing needed federal financial and technical support to build a new canal that would deliver Colorado River water to the Imperial Valley through lands entirely within the U.S. (thus, the "All American Canal"). The 1928 Act also responded to the urgency of Los Angeles interests who wanted a reliable supply of hydroelectric power and a future water source. Because of the potentially heavy demands that these proposed uses would put on the river, the Boulder Canyon Project Act also expressly recognized "satisfaction of present perfected rights" as a purpose of the dam.

Further, Article VIII of the Compact provides:

Whenever storage capacity of 5,000,000 acre-feet shall have been provided on the main Colorado River within or for the benefit of the Lower Basin, then claims of such [present perfected] rights, if any, by appropriators or users of water in the Lower Basin against appropriators or users of water in the Upper Basin shall attach to and be satisfied from water that may be stored not in conflict with Article III.

Under normal operation of the prior appropriation doctrine, a senior downstream appropriator can protect a right to water by placing a "call" on the stream, thereby preventing a junior upstream user from exercising a competing right to water. However, construction of Hoover Dam, by interposing a reservoir - Lake Mead - to buffer demands of the two Basins, obviated the possibility that Lower Basin present perfected rights would seek to impose a call on Upper Basin present perfected rights.

Nevertheless, it remained for litigation in the U.S. Supreme Court many years later to produce a definition of present perfected rights. In the 1964 Decree implementing its decision in Arizona $v$. California, the Court defined a perfected right as

a water right acquired in accordance with State law, which right has been exercised by the actual diversion of a specific quantity of water that has been applied to a defined area of land or to definite municipal or industrial works, and in addition shall include water rights created by the reservation of mainstream water for the use of Federal establishments under Federal law whether or not the water has been applied to beneficial use; . . (376 U.S. $340,341,1964)$.

The Court included as perfected rights in the Lower Basin those established as of the effective date of the Boulder Canyon Project Act (June 25, 1929). The Court also recognized tribal reserved water rights under the so-called "Winters Doctrine" [from United States $v$.' Winters, 207 U.S. $56 \div(1908)]$ as being present perfected rights. Moreover. the Court ruled that, in any year in which less than 7.5 maf of Colorado River water is available for consumptive use in the Lower Basin states (Arizona, California, and Nevada), the Secretary of the Interior is to administer the river so as to satisfy first all those holding present perfected rights and to do so on a chronological priority basis without regard for state lines.

In its 1964 Decree, the Supreme Court also recognized a process for identifying and quantifying present perfected rights to use Colorado River water in the Lower Basin. In a 1979 Supplemental Decree, the Court specified these rights in the three states by priority date and by annual quantity of water that may be diverted [(Arizona v. California, 439 U.S. 419 (1979)]. Present perfected rignts total more than 4 maf, including nearly 3 maf in California. Tribal water rights which are also present perfected rights, total about 900,000 acre-feet, most of which are in Arizona. Since most Indian water rights have not yet been put to consumptive use by their tribal owners, increased utilization of those rights by the tribes could exacerbate the effects of severe, sustained drought on other lower-priority users.

\section{WATER FOR THE LOWER BASIN}

While the 1922 Compact segmented the Colorado River into two basins with the dividing point at Lee 
Ferry in Arizona, just below the present site of Glen Canyon Dam, that division assigned a higher priority to the Lower than to the Upper Basin. Each Basin is apportioned the "exclusive beneficial consumptive use" of 7.5 maf of water per year (including present perfected rights), and the Lower Basin is "given the right" to use an additional 1 maf. The apportionment, however, operates as a delivery guarantee in favor of the Lower Basin rather than a division of available waters.

Article III(d) of the 1922 Compact prohibits the Upper Basin from depleting the Colorado River, measured at Lee Ferry, below an aggregate of 75 maf of water in any ten-year period. Moreover, under Article III(e) of the Compact, the Upper Basin cannot "withhold" water that "cannot reasonably be applied to domestic and agricultural uses." Since the Upper Basin still has not developed consumptive water uses approaching its 7.5 maf-per-year ceiling, the practical effect of these provisions is generally to assure that the Lower Basin will receive at least 7.5 maf per year on average and potentially more in many years. Thus, while the Compact purported to apportion the Colorado River equally between the two Basins, in fact it works primarily to generate deliveries of water to certain water users in Arizona, California and Nevada. Congress further ensured that the Upper Basin would be able to meet its delivery obligations to the Lower Basin by authorizing construction of Glen Canyon Dam (and three other large projects in the Upper Basin) in the Colorado River Storage Project Act of 1956.

The emphasis on providing a minimum delivery of 7.5 maf per year to the Lower Basin is also evident in the way in which the Secretary of the Interior, under general congressional direction, has decided to operate Hoover Dam and Glen Canyon Dam. Section 602(a) of the Colorado River Basin Project Act of 1968 directed the Secretary of the Interior to develop longrange operating criteria ("operating criteria") for these reservoirs. The Secretary's present operating criteria call for a "minimum objective release" of $\mathbf{8 . 2 3}$ maf per year from Lake Powell (calculated by annualizing the ten-year 75 maf obligation to $7.5 \mathrm{maf}$, adding the Upper Basin's one-half share of the 1.5 maf Mexico commitment, and subtracting 20,000 acre-feet as the estimated annual inflow from the Paria River which enters the Colorado River below Glen Canyon Dam but above Lee Ferry). More than this amount of water must be released whenever storage in Lake Powell exceeds a certain level, but a minimum release of 8.23 maf is required regardless of water conditions in the Upper Basin. The Secretary is to review the operating criteria at least every five years and is authorized to make changes at those times.
Elements of the Law of the River also make allocations within as well as to the Lower Basin and establish priorities among states, among some users, and among certain uses in the Lower Basin. Perhaps most important is the 1963 U.S. Supreme Court decision in Arizona $v$. California, which found that, as a result of the 1928 Boulder Canyon Project Act, California held an allocation of 4.4 maf, Arizona 2.8 maf, and Nevada 300,000 acre-feet. If less than 7.5 maf of water is available, the Secretary has discretion to apportion the shortages. Present perfecied rights must be satisfied first.

In 1929 the California legisiature affirmatively recognized that its apportionmen: was limited to 4.4 maf as required by the Boulder Canyon Project Act. Then major Southern California water users established priorities among themselves to certain quantities of Colorado River water uncier a 1931 Seven Party Agreement. The first three priorities (for 3.85 maf of water) went to agricultural water uses in the Palo Verde Valley, Yuma Project Reservation Division), Imperial Valley, and Coachella Valley (representing over 2.8 maf of present perfec:ed rights); fourth priority (for 662,000 acre-feet) we:t: to Metropolitan Water District of Southern California (MWD). Rights to unused or "surplus" supplies above 4.4 maf) go first to MWD $(662,000$ acre-feet, oi which 112,000 was allocated to San Diego) and then to the four irrigation districts (300,000 acre-feet).

The Colorado River Basin Project Act specifically gave California a higher priority to receive its $4.4 \mathrm{maf}$ of water than any diversions to provide water for the Central Arizona Project (CAP:. Arizona agreed to subordinate its CAP diversion rights in return for California's support for the projecs, which was authorized in 1968. The operating criceria for Hoover Dam describe three general opera:ing conditions: normal, in which annual releases proitide 7.5 maf per year to meet Lower Basin uses; surplus, in which additional water will be released; and shortage, in which the Secretary has the discretior. to release less than 7.5 maf. In a shortage situaticn. all present perfected rights must first be satisfiez and then the remainder of California's 4.4 maf. Nevada's contract deliveries must be satisfied ahead $c:$ jeliveries to the CAP. Thus, by virtue of the Lowe- Basin's higher priority and especially California's preferred position therein, the Law of the River effectively shifts the burden of the consequences of severe, s:iscained drought, to Arizona and ultimately to the $L_{\text {?per Basin. }}$ 


\section{WATER FOR THE UPPER BASIN}

The 1922 Compact appeared to apportion the beneficial consumptive use of 7.5 maf per year of Colorado River water to the Upper Basin. In fact, the amount actually available for use depends on available supplies and quantities in storage. In 1948 the Upper Basin states worked out a compact allocating their respective shares of Colorado River water. The Upper Colorado River Basin Compact ("Upper Basin Compact") allocated 50,000 acre-feet of annual consumptive use from the Colorado and Little Colorado Rivers to Arizona and then apportioned use of the remaining waters among the states of Colorado ( 51.75 percent), New Mexico (11.25 percent), Utah (23 percent), and Wyoming (14 percent) (see Table 1 below). The effect of the allocation is shown in Table 1 . As shown, present uses are well below the theoretical 7.5 maf apportionment and are well within the supply capacity of the Colorado River under the historical average flow conditions derived from tree-ring studies (13.5 maf). Assuming the storage buffer has been exhausted, shortages begin to arise in some states as annual flows decline below 14 maf.

In anticipation of possible shortages, the 1948 Compact established the Upper Colorado River Commission ("Commission") and empowered the Commission to order curtailments of consumptive uses in the Upper Basin as required to meet downstream delivery obligations. As discussed more fully in the next section, Article IV(b) provides that, in the event of curtailment, any state that has exceeded its water allocation in the immediately preceding ten years must deliver the entirety of its aggregate overage to Lee Ferry in the year of the call, or a sufficient portion thereof to enable the Upper Basin to meet its delivery obligations under Article III of the Colorado River Compact.
Under Article IV(c), once aggregate overdrafts have been supplied, any remaining required curtailments are to be allocated among the four states in the same proportion as the previous water year's actual consumptive use bears to total consumptive uses in the Upper Basin, without regard for consumptive uses under present perfected rights. In addition, Article VII(d)(1) authorizes the Commission to make and report findings to the President as to whether the shortage provision of Article 10 of the Treaty with Mexico should be invoked.

Enactment of the Upper Colorado River Basin Compact cleared the way for federal support of the construction of major storage projects in the Upper Basin. The Colorado River Storage Project Act of 1956 authorized four projects: Curecanti (now the Aspinall Unit) on the Gunnison River in Colorado, Navajo Dam on the San Juan River in New Mexico, Flaming Gorge Dam on the Green River in Utah, and Glen Canyon Dam on the Colorado in northern Arizona. Construction of these additional storage facilities thus reflects a recognition that the Upper Basin would bear the burden of risk associated with the initial miscalculation of the likely annual flows of the Colorado River.

\section{LEGAL REQUIREMENTS AND OPPORTUNITIES IN RESPONDING TO A SEVERE SUSTAINED DROUGHT}

The preceding sections describe the general priorities by which decisions to allocate Colorado River water would presumably be made in a period of prolonged drought. Within this priority structure, however, flexibility to cope with severe, sustained drought varies. Thus, for example, while the treaty obligation to Mexico holds the highest priority, it also

TABLE 1. Consumptive Uses Allowed by the Upper Basin Compact.

\begin{tabular}{|c|c|c|c|c|c|c|}
\hline \multirow[b]{2}{*}{ Recipient } & \multirow{2}{*}{$\begin{array}{l}\text { Compact } \\
\text { Percent } \\
\text { (percent) }\end{array}$} & \multicolumn{4}{|c|}{ Assumed Flow Conditions* } & \multirow[b]{2}{*}{$\begin{array}{c}\text { Actual Uses** } \\
\text { (1981-1985 average) }\end{array}$} \\
\hline & & $\begin{array}{l}\text { at } 16 \\
\text { maf }\end{array}$ & $\begin{array}{l}\text { at } 14 \\
\text { maf }\end{array}$ & $\begin{array}{l}\text { at } 12 \\
\text { maf }\end{array}$ & $\begin{array}{l}\text { at } 10 \\
\text { maf }\end{array}$ & \\
\hline Arizona & & .05 & .05 & .05 & .05 & .04 \\
\hline Colorado & 51.75 & 3.86 & 2.95 & 1.91 & .88 & 1.99 \\
\hline New Mexico & 11.25 & .84 & .64 & .42 & .19 & .38 \\
\hline Utah & 23.00 & 1.71 & 1.31 & .85 & .39 & .66 \\
\hline Wyoming & 14.00 & 1.04 & .80 & .52 & .24 & .33 \\
\hline Upper Basin Tolal & 100.00 & 7.5 & 5.75 & 3.75 & 1.75 & 3.40 \\
\hline
\end{tabular}

*Assu mes that a minimum of 8.25 million acre.feet of water must go to the Lower Basin.

**Bureau of Reclamation, Colorado River System Consumptive Uses and Losses Report, 1981 -1985 (June 1991.. 
incorporates a mechanism by which the actual annual delivery may be reduced. More specifically, while the CORN computer model used for analysis of Colorado River operations in this project assumes that deliveries to Mexico will not be reduced until there is no storage remaining in Lake Mead, in fact the Treaty suggests the possibility of reducing deliveries to Mexico if any consumptive uses of Colorado River water in the U.S. are reduced. It seems likely that this provision would be invoked before Lake Mead is drained, but it is far from clear what that point would be. In any event, relatively little water would be saved by the U.S. under this provision.

Similarly, while operation of the Colorado River is heavily weighted toward assuring deliveries to the Lower Basin, and particularly the 4.4 maf allocated to California and the water allocated to pre-1968 users in Arizona and Nevada, the Secretary of the Interior has some discretion in deciding how to allocate shortages among Lower Basin users. Section 301(b) of the Colorado River Basin Project Act directs the Secretary to satisfy present perfected rights first, other water contract holders in California (up to the 4.4 maf allocation) second, and other contract holders and federal reservations in Arizona and Nevada third. Deliveries to the Central Arizona Project are to be curtailed as necessary to meet these other Lower Basin uses.

At present the Secretary has no explicit guidance by which to declare a shortage situation in the Lower Basin (that is, when there is inadequate water to release 7.5 maf for consumptive uses). The Bureau of Reclamation's Colorado River model assumes a shortage exists when the elevation of Lake Mead reaches 1095 feet (12 feet above the nominal minimum power pool and approximately 40 percent of active storage capacity). At this point CAP deliveries are assumed to drop abruptly from roughly 1.3 maf to 800,000 acrefeet per year. Further reductions would be made as necessary to meet present perfected rights and other contract rights established on the basis of the 7.5 maf Lower Basin apportionment.

Section 602(a) of the 1968 Colorado River Basin Project Act prioritizes the operation of the Upper Basin reservoirs and particularly Lake Powell, first, to supply the Upper Basin's Mexico delivery obligation; second, to meet the Colorado River Compact's requirement that the Upper Basin not cause the tenyear flow at Lee Ferry to be less than $\mathbf{7 5}$ maf; and third, to make additional releases determined to be reasonably usable by the Lower Basin without impairment of existing consumptive uses in the Upper Basin. The 1968 Act appears to require releases from Lake Powell as necessary to equalize its storage with that of Lake Mead. As discussed above, the operating criteria for Glen Canyon Dam establish a "minimum objective release" of at least 8.23 maf per year. More water may be released when there is a "surplus" but no adjustments are made in low flow years to compensate for releases in excess of 8.23 maf in high flow years. Such operations may satisfy Section 602(a) of the 1968 Act but create an inflexibility not required by the 1922 Compact which only places a ten-year - not an annual - delivery obligation on the Upper Basin.

Neither the 1968 Act nor the operating criteria provide for management of the Lpper Basin reservoirs in anticipation of or under actual conditions of prolonged drought. Rather, all attention is focused on assuring the availability of at least. .5 maf annually of consumptive uses in the Lower Basin, and on the circumstances under which more water may be released to satisfy Lower Basin demancs compatible with optimum generation of electric power. The emphasis on optimizing power generation has been moderated somewhat by the Grand Canyon Protection Act of 1992, which forces consideration of recreational as well as fish and wildlife concerns. Though not prescriptive beyond its terms, the 1992 Act could inform the exercise of Secretarial ciscretion throughout the Basin.

Unlike the Colorado River Compact and subsequent statutes relating to the Colorado River, the Upper Basin Compact addresses the potential condition of inadequate water to meet consumptive uses. Such attention is perhaps not surprising in view of the direct linkage in the Upper Basin Compact between possible curtailment of Upper Basin uses and meeting the downstream commitments established in the 1922 Colorado River Compact. However, some ambiguity remains in the meaning of the "principles" that are to guide the Upper Colorado River Commission in ordering curiailments. First recourse is to those states consumptively using more water than they were entitled to inder the Upper Basin Compact during the immediately preceding ten-year period. Except for Arizona ishich has a fixed allocation of 50,000 acre-feet per year), each of the Upper Basin states has an allocation to consume a specified percentage of what was assumed to be 7.5 maf per year (less the Upper Basin's share of the delivery request for Mexico and up to 50,000 acre-feet per year for Arizona). Curtailments are to be made on the basis of the percentage of ine downstream delivery obligation created by a state $s$ share of the total consumptive use of Colorado River water in the Upper Basin during the preceding :ear. Consumption related to water rights perfectec in Upper Basin states prior to November 24, 1922. is to be excluded from this calculation.

In sum, the collective pieces of the Law of the River create a more or less well-derined set of requirements 
by which shortages of Colorado River water are to be allocated among the large number of consumptive users in the Basin. In fact, much less attention has been given to questions of allocating shortages than to allocating "surpluses." Emphasis has been placed on avoiding shortages through the construction of a massive water storage system and on operating it to assure delivery of at least the minimum contracted allotments within the Lower Basin.

An earlier study of severe sustained drought in the Colorado River Basin ("Phase I Report," Gregg and Getches, 1991) included an analysis of water allocation under existing legal and institutional arrangements. That study assumed levels of drought severity drawn from reconstructed flows based on tree-ring studies covering a 400-year period and accounted for water sources available to California and Arizona in addition to the Colorado River. It attempted to determine the performance of existing water delivery and distribution systems. The report concluded that under the existing legal and institutional regime, most of the agricultural, municipal, and industrial consumptive water uses in the two states studied can be maintained even during a severe, sustained drought. However,

there would ... be noticeable and progressive losses of resources dependent on regular minimum stream flows and runoff. Quality of life also would begin to decline with such losses and with the inevitable restrictions on outdoor water use for irrigation of yards, parks and golf courses (Gregg and Getches, 1991, Part II, p.117).

The anticipated effects of drought on consumptive uses are arrayed on Table 2 (Table 5-3 in the Phase I Report). The report cautioned, however, that the present cushion against feeling the effects on drought on consumptive uses would soon be eliminated by growth in demand:

Ongoing expansion of the population and economy of the area will put new pressures on the system and eventually exceed its capacity.... For a while growth can be sustained by using existing supplies more efficiently. . . . But if growth continues, these savings will be consumed and further demand reduction will require alterations in lifestyle. The area must eventually turn to reallocation of existing rights, mostly rights now held by agricultural users. Choices among urban lifestyle, agricultural cutbacks and growth control are bound to be controversial (Gregg and Getches, 1991, Part II, p.10).
Thus, the existing cushion against severe, sustained drought in the Colorado River Basin is diminishing, affording only a temporary window of opportunity for policy makers to anticipate, consider, and plan for the eventual loss of existing flexibilities.

\section{IN-PLACE USES OF COLORADO RIVER WATER}

Beginning with the 1922 Compact, the Law of the River has focused predominantly on "consumptive" uses of the water of the Colorado River: apportionment of the river's water is described in terms of "beneficial consumptive use." It should not be surprising, then, that the Phase I Report predicted that natural systems and environmental values would feel the worst effects of a major drought. Nothing in this analysis suggests a different conclusion.

In-place, nonconsumptive uses have been gaining in importance. One of these values - hydroelectric power generation - was recognized as a secondary or "incidental" use for the major federal water storage facilities in the Basin but is, in fact, the major source of revenue returning the substantial cost of these facilities to the U.S. Treasur: The importance of protecting water quality received official recognition in the Colorado River Basin Saiinity Control Act of 1974. The water needs of endangered fish species emerged as a major issue beginning in the late 1970 s with the implementation of the Endangered Species Act in the Basin. And the importance of the recreational aspects of the Colorado River to the Grand Canyon National Park was acknowledged in the Grand Canyon Protection Act of 1992.

Hydroelectric power generation has not affected the annual quantities of consumptive use water available to those holding apportionments of water from the Colorado River, at least in years when flows are normal or above. Rather, the primary effect of hydroelectric generation has been to determine the hourly schedule by which varying amounts of the storage water are released during the year (for example, releasing more water to meet peaking power demands). Concerns have emerged about other values of the Colorado River, such as recreational interests in the Grand Canyon and seasonal flow needs of endangered fishes below Flaming Gorge Reservoir. These concerns have led to changes in the patterns of water storage releases, sometimes interfering with maximization of hydroelectric power revenues. In a prolonged drought, the ability to operate reservoirs in a manner favorable to hydroelectric power generation purposes will be further constrained.

Salinity concentrations in the Colorado River could potentially affect the quantities of water available for 
TABLE 2. Possible Effects on Water Supplies of Sludy Area of Various Length Droughts.

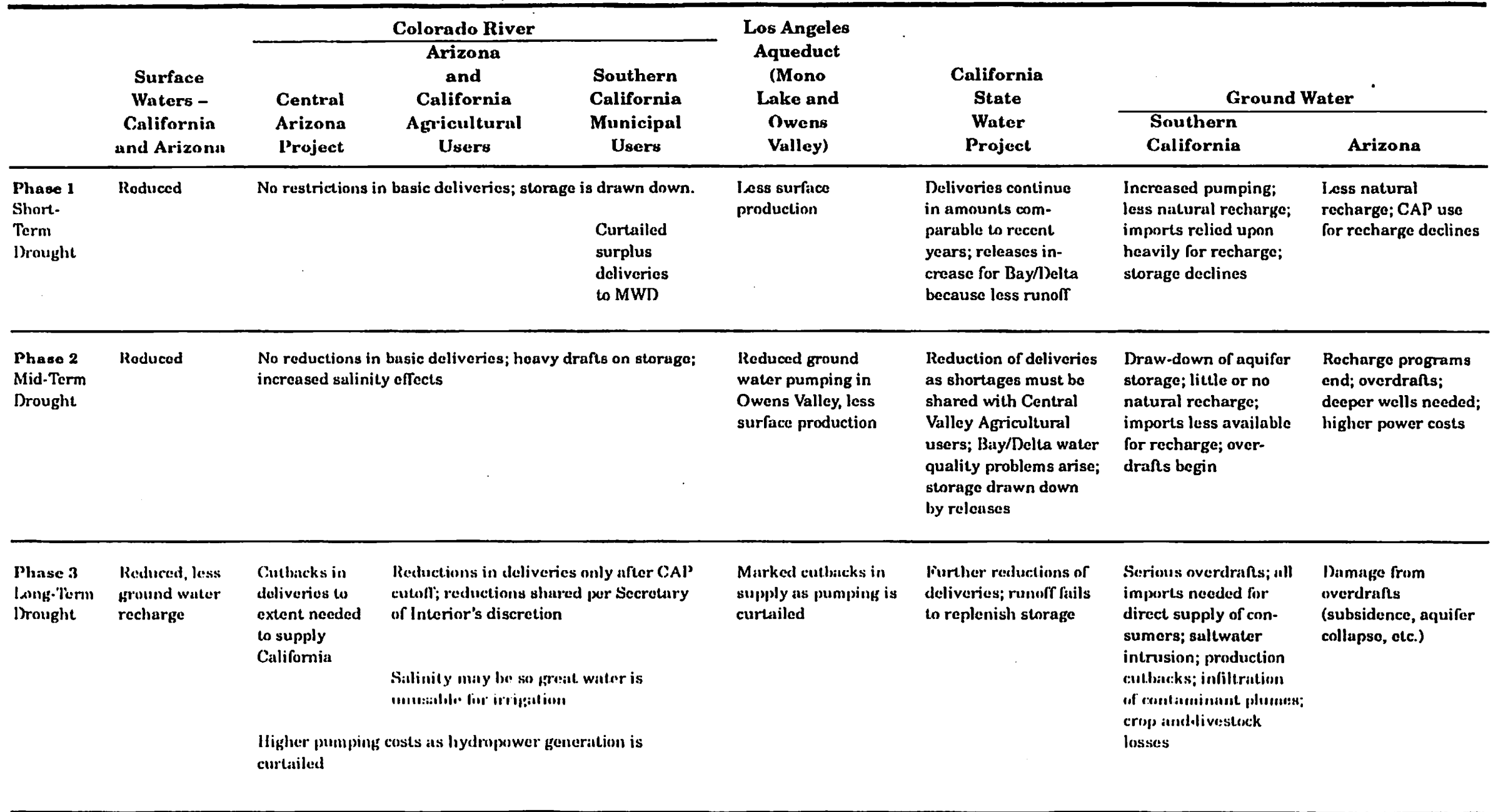


consumptive use in a period of prolonged drought (Miller et al., 1986). Minute 242 of the U.S.-Mexico International Boundary and Water Commission guaranteed Mexico that the annual average salinity of the Colorado River coming into Mexico will not exceed the salinity measured at Imperial Dam (the diversion point for the Imperial Valley in California) by more than 115 parts per million, plus or minus 30 . The United States constructed the Yuma Desalting Plant so that desalted water could be blended with Colorado River water if necessary to meet this obligation. In 1976 the Environmental Protection Agency approved salinity standards for the Colorado River at three locations including Imperial Dam. Because of the substantial natural sources of salinity entering the Colorado River, the salinity added by return flows of diverted water, and the substantial out-of-basin exports of Colorado River water, prolonged drought is likely to increase greatly the salinity concentrations in the remaining flows. In theory at least, consumptive uses of Colorado River water might have to be reduced to meet water quality requirements.

The requirements of the Endangered Species Act may impose the most noticeable constraints in allocating water during the shortages that would arise in the event of a severe sustained drought. The Act protects four endangered fish species in the Colorado River Basin: the Razorback Sucker, the Colorado Squawfish, the Humpback Chub, and the Bony-Tail Chub. Most of the remaining populations of these fishes are found in the Upper Basin, and a recovery plan intended to restore these species to viable condition is in place (U.S. Fish and Wildlife Service, 1993). An important element of the recovery plan is to provide adequate streamflow conditions in essential habitat areas. Moreover, virtually the entire Colorado River has been designated as "critical habitat" for one or more of the endangered fish species (Federal Register, 1994). Under the Endangered Species Act, the Secretary of the Interior has an obligation to protect listed species including these Colorado River fishes. During a prolonged drought, it is probable that the Secretary would be required to take account of the flow-related needs of the fishes as well as consumptive use commitments under the Law of the River. The potential effects of the Secretary's possible alternative courses of action remain to be analyzed.

\section{LEGAL OPTIONS FOR MANAGING A SEVERE SUSTAINED DROUGHT}

This assessment suggests that the existing legal and institutional framework governing the Colorado River does not adequately address issues that would be raised by a severe, sustained drought. Indeed, surprisingly little attention appears to have been given this eventuality in the development of the Law of the River, leading to recommendations in 1991 that a new basinwide entity be established to deal with the multiple emerging issues on the Colorado River with participation by a wide range of interests (Getches, 1991). The recommendations of the Phase I Report emphasized improved planning. groundwater storage and management, optimizing management of Colorado River reservoirs, reallocation of existing supplies through transfers and marketing, and management of water demand, as well as formation of a Colorado River basinwide organization.

Where some provision has been made in the Law of the River for addressing water shortages, a number of important ambiguities and uncertainties remain. Priorities have been set for sharing shortages as between the U.S. and Mexico, between the Upper and Lower Basins, and among the states within each of the Basins. However, in some cases, these choices have not been made explicit, nor have they been evaluated in relation to other unquantitied demands for the water, such as endangered species protection, recreational demands, or Indian reserved rights.

Except for the Central Utan Project, as recently modified by Congress, and perhaps the AnimasLaPlata Project, it seems unlikely that other major water storage facilities will be constructed in the Colorado River Basin in the foreseeable future. The Central Arizona Project is now virtually complete and is capable of delivering Arizona's full entitlement of Colorado River water. Consumptive demands in the Upper Basin, particularly Colorado, continue to increase at a modest rate. With the river essentially fully developed, it is time for a broad and comprehensive examination of how the Colorado River is being managed and used, and for consideration of changes in the present framework. The ability of this region to respond to a severe sustained drought should be a part of such an investigation.

The 1968 Colorado River Basin Project Act sets out a broad directive to the Secresary of the Interior to develop a "regional water plan" for ensuring an adequate water supply for the Colorado River Basin. Originally envisioned as a study of transbasin water diversion to augment Colorado River Basin supplies, this directive could now be applied to make a basinwide assessment of opportunities for improving overall management of the Colorado River and its many water regulation and diversion facilities. It could be undertaken by the federal government or delegated to a new entity representing fecieral, state, tribal, and non-governmental interests.

An additional objective of undertaking the statutorily-authorized basinwice water plan could be 
to identify institutional mechanisms and guidelines by which voluntary interstate agreements altering existing uses of Colorado River water could be made. One such approach, though politically and legally difficult at present, would be to permit a market-driven . allocation system to operate within the Colorado River Basin. There is little doubt that a market permitting both intrastate and interstate purchase and sale of allocations to use Colorado River water would provide a more flexible mechanism for meeting changing water demands in the Basin. Presumably such a market would take account of the security of the allocation in times of water shortage, and "higher priority" allocations would move to uses that most value this security of supply.

There have been several proposals in recent years for interstate marketing of Colorado River water (Guy, 1991). For the most part, these proposals have been privately arranged transactions and have been unenthusiastically received by the Basin states. In 1991 California proposed a state-managed water bank in the Colorado River Basin with limited authority to facilitate water transfers (California, 1991). The proposal failed to win support from several affected states.

Interstate transfers or other incentive-based approaches for voluntarily transferring water uses among users in different states within the Colorado River Basin ultimately seem likely. As the water resources of the Basin become scarcer, the economic attractiveness of allowing such transactions will overcome existing obstacles. It seems especially likely that there will be such arrangements made among the states in the Lower Basin. One possible match, for example, is between water-short Nevada and contractors unable to pay for Central Arizona Project water. The Metropolitan Water District of Southern California (MWD) and the Central Arizona Water Conservation District (CAWCD) have already pioneered a creative interstate arrangement by which "surplus" flows in the Colorado River would be stored in underground basins in Arizona for potential future use by MWD and CAWCD (Arizona-California Agreement, 1992).

Efforts to design a regional water plan to facilitate interstate water markets, or to undertake a comprehensive evaluation and use of basin facilities, are constrained by the structure of existing institutions. There is no basinwide forum or other entity for undertaking comprehensive planning or for discussing and solving issues of common interest throughout the region. Creation of such an entity as recommended in the Phase I Report would furnish an institutional framework for facilitating water marketing and water banking (Getches, 1991).
As evidenced by the gradual accretion of the Law of the River, problems with the management of the Colorado River and adaptation to changing conditions have traditionally been addressed on an ad hoc basis. While this demonstrates some flexibility in the Law of the River, the parties involved rarely include all the affected interests. Official federal and state representatives have dominated management and controlled change in the law. Interests such as Indian tribes and environmental groups have been left out and relegated to using legal and political devices to hold up decisions or transactions that may be objectionable to them. Thus, we reiterate the suggestion for the establishment of a basinwide entity as a forum for convening a variety of interested parties to facilitate coping with the threat of drought as well as finding solutions to Colorado River issues (Getches, 1991).

Rigidly applied, the Law of the River is not well suited to deal with the issues likely to arise in the event of a severe, sustained drought. While the probability of such a drought remains unknown, the prospect is generally acknowledged. Even if the probability of a major prolonged arought is low, there is still much to be learned by evaluating the manner in which shortages would be allocated by the existing legal framework. Free of the stress and urgency of imminent drought, the present affords an opportunity to consider whether the priorities imposed and the trade-offs permitted by the legal framework are desirable and acceptable. To the extent the present framework does not promote wise decisions, it is timely to weigh institutional options and to explore creative alternatives to the existing structure.

\section{ACKNOWLEDG.IENTS}

A portion of the financial suppor for researching this article was from the U.S. Geological Surve; Department of the Interior, under Award No. 14-08-0001-G1892. This article is a product of the Natural Resources Law Center, a research and public education center at the University of Coloraco School of Law. The Center maintains its position of neutrality on issues of public policy in order to safeguard the intellectual ireedom of its staff and those with whom it associates. Thus, interpretations or conclusions in Natural Resources Law Center publicztions should be understood to be solely those of the author(s) ans should not be attributed to the Center, the University of Colorado, the State of Colorado, or any of the organizations that suppor. Natural Resoures Law Cen. ter research.

\section{LITERATURE CITED}

Agreement Between The Central Arizona Water Conservation District and the Metropolitan Water District of Southern California for a Demonstration Project on Cinderground Storage of Colorado River Water, Oct. 15, 1992 "Arizona-California Agrecment"). 
Arizona v. California, 373 U.S. 546 (1963).

Arizono v. California, 376 U.S. 340, 341 (1964).

Arizona v. California, 439 U.S. 419 (1979).

Boulder Canyon Project Act, 43 U.S.C. $\$ 617$ (1988).

Colorado River Basin Act, 43 U.S.C. \$ 1521 (1988).

Colorado River Basin Project Act 301(b), 43 U.S.C. 1501 (1988)

Colorado River Basin Project Act § 602(a), 43 U.S.C. § 1501 (1988).

Colorado River Compact, H. R. Doc. No. 605, 67th Cong., 4th sess., (1923) pp. 8-12, Article III.

Colorado River Storage Project Act, 43 U.S.C. \$ 620 (1988).

Federal Register, Vol. 58, p. 6578 (1993). Endangered and Threatened Wildlife and Plants: Determination of Critical Habitat for the Colorado River Endangered Fishes, (to be codified at $\mathbf{5 0}$ C.F.R. pt. 17).

Getches, David H., 1985. Competing Demands for the Colorado River. University of Colorado Law Review 56:413-479.

Getches, David H., 1991. Water Allocation During Drought in Arizona and Southern California: Legal and Institutional Respanses. In: Severe Sustained Drought in the Southwestern United States, Phase I Report, Frank Gregg (Principal Investigator) and David H. Getches (Co-Principal Investigator). Article reprinted as a monograph available from the Natural Resources Law Center, University of Colorado (David H. Getches, Water Allocation During Drought in Arizona and California: Legal and Institutional Responses, 1991).

Gregg, Frank (Principal Investigator) and David H. Getches (CoPrincipal Investigator), 1991. Severe Sustained Drought in the Southwestern United States, Phase I Report. Available from National Technical Information Service, Springfield, Virginia. PB92115013.

Guy, David, 1991. When the Law Dulls the Edge of Chance: Transferring Upper Basin Water to the Lower Colorado River Basin. Utah Law Review 1991(1): 25-54.

Hundley, Norris, 1966. Dividing the Waters: A Century of Controversy Between the United States and Mexico. University of California Press, Berkeley, California.

Hundley, Norris, 1975. Water and The West: The Colorado River Compact and the Politics of Water in the American West. University of California Press, Berkeley, California.

Kneese, Allen V. and Gilbert Bonem, 1986. Hypothetical Shocks to Water Allocation Institutions in the Colorado Basin. In: New Courses for the Colorado River, Gary D. Weatherford and P. Lee Brown (Editors). University of New Mexico Press, Albuquerque, New Mexico, pp. 89-91.

Mexican Water Treaty and Protocol, 59 Stat. 1219 (1944).

Miller, Taylor O., Gary D. Weatherford, and John E. Thorson, 1986. The Salty Colorado. The Conservation Foundation, Washington, D.C.

State of California, 1991. Conceptual Approach for Reaching Basin States Agreement on Interim Operation of Colorado River System Reservoirs, California's Use of Colorado River Water Above Its Basic Apportionment, and Implementation of an Interstate Water Bank (prepared for Colorado River Basin States Meeting in Denver, Colorado, August 28, 1991).

Stockton, Charles and Gordon Jacoby, Jr., 1976. Long Term Surface Water Supply and Streamflow Trends in the Upper Colorado River Basin, Lake Powell Research Project Bulletin No. 18, March 1976.

United States Department of the Interior, Bureau of Reclamation, 1991. Colorado River System Consumptive Uses and Losses Report, 1981-1985. Published by Bureau of Reclamation, Salt Lake City, Utah.

United States Department of the Interior, Fish and Wildlife Service, 1993. Recovery Implementation Program for Endangered Fish Species in the Upper Colorado River Basin. Published by U.S. Fish and Wildlife Service, Denver, Colorado.

Weatherford, Gary D. and F. Lee Brown, 1986. New Courses for the Colorado River. University of New Mexico Press, Albuquerque, New Mexico. 